\title{
Coffee Toffee Matters: Organizational Culture, Employee Communication, Leadership Style and Work Motivation
}

\author{
T S Wibowo ${ }^{1}$, C M Srihandayani ${ }^{2}$ \\ \{tonysus_sw@unipasby.ac.id ${ }^{1}$, menukch@unipasby.ac.id $\left.{ }^{2}\right\}$ \\ Universitas PGRI Adi Buana Surabaya, J1 Dukuh Menanggal XII No 4 Surabaya, 60234, \\ Indonesia ${ }^{1,2}$
}

\begin{abstract}
Profit-oriented organizations with intense competition such as cafes must have adequate human resources to create innovations in order to achieve organizational goals. Important factors in achieving these goals are organizational culture, employee communication, and leadership style, and work motivation as well. This study uses three independent variables, namely organizational culture, employee communication, and leadership style, while the dependent variable is work motivation.The object of research in this study is the Coffee Toffee cafe in the city of Surabaya. Data analysis using multiple linear regression with a sample of 40 cafe employees using questionnaire instruments. From partial data processing, it is known that organizational culture has a significant effect on work motivation at a significance level of 0.014 . While employee communication variables and leadership style did not significantly influence work motivation. In simultaneous tests, organizational culture, employee communication, and leadership style have a significant effect on work motivation.
\end{abstract}

Keywords: Organizational Culture, Employee Communication, Leadership Style, Work Motivation.

\section{Introduction}

Information Technology development should be followed by increasing services in various business sectors, especially the services sector. Human resources play an important role in organization's efforts to gain profits and win the competition. Related to human resources, it can not be separated from the management of the company which related to management disciplines within the scope of organizational culture, as well as the role of employees in achieving goals through effective and efficient employee communication. The efforts of the organization to achieve goals are also inseparable from the role of the company's leaders to direct its members, therefore a leadership style will be formed that is in accordance with the conditions of the organization.

The important role of human resources also applies to companies with service outcomes that have special characteristics where services are abstract and can only be felt by consumers. This condition also occurs in cafes, where service and innovation are successful keys to win the competition and maintain the trust of service users. However, conditions in the field can be 
different because of many factors, and that creates a gap between company expectations and consumer expectations.

From the various conditions of the gap above, the researchers are interested in trying to uncover the causes of inequality in terms of human resource side and organizational, where the object of research is the Coffee Toffee café in the city of Surabaya. Some of the underlying reasons for choosing a Coffee Toffee cafe are an intense competition where many businesses in the same field also with similar concepts, so the company must strive to attract consumers by presenting uniqueness and distinctive features from cafes that are now part of the lifestyle, especially young people and business people.

From the description of the background above, the problem can be formulated as follows: 1). How the organizational culture, employee communication, and leadership style and employee motivation at Coffee Toffee Café Surabaya?[1]. Do organizational culture, employee communication, and leadership style influence employee motivation at Coffee Toffee Café Surabaya?

Purpose of Research:1) Describe organizational culture, employee communication, and leadership style and work motivation of employees at Coffee Toffee Café in Surabaya.2) Analyzing an organizational culture, employee communication, and leadership style as well as employee motivation at Coffee Toffee Café in Surabaya.

Research Contribution For managers and business owners it can be used as an alternative development and decision making in the field of human resources so that it is expected that there will be an increase in service at the café and be able to win the competition.

\section{Literature Review}

Previous research was conducted by Giantari and Riana[1] with a variable such as organizational culture, work motivation and performance, and the object of research at Klumpu Bali Resort, Sanur. Data collection is done through primary data with a questionnaire to 52 employees using saturated samples, means census research where the number of samples is equal to the population. Data processing using descriptive analysis, confirmatory factor analysis, and path analysis. Furthermore, the results of the study concluded that organizational culture has a positive and significant effect on employee motivation. In the next findings also said that organizational culture and work motivation have a positive and significant effect on employee performance, where in one condition if the organizational culture gets better and work motivation gets higher, it can have an effect on improving employee performance.

The main difference from the current research is from the main focus side in this case the independent variables are very different, research location, research time, data analysis and population characteristics. Whereas the similarity with the previous research from the side of the organizational culture variable and the character of the research object, where the product is a service.

\subsection{Organizational Culture}

In the implementation of the practice of human resources, culture is an important factor in achieving organizational goals translating through vision and mission, which is then retranslated through the organization's operational objectives and procedures so that it can be implemented by all employees. The results of the research show that organizational culture and learning organization can be adopted as agents to improve organization effectiveness[2]. 
According to Awadh and Alyahya[3] A dimension of organization culture that has been one of prominent research findings shows that the culture in an organization arises from values and norms in an organization and originates from the inter-personal relationship among its members. The description of organizational culture was also expressed by King [4] which says the topic or key terms in organizational cultures define as a system of values that subconsciously and silently drives people to make each choice and decision in the organization. Whereas according to Wibowo [5] culture is a pattern of human activity which is systematically passed down from generation to generation through various learning processes to create a particular way of life that best fits the environment.

From some expert opinions above, we can draw a common thread that organizational culture is the implementation of values and norms agreed upon by members of the organization with the process of interaction and communication and learning to achieve goals.

In this study, indicators of organizational culture use the dimensions proposed by Robbins and Judge [6] where there are seven primary characteristics which together capture the nature of organizational culture, namely:

a. Innovation and risk-taking. How far the employees are encouraged to be innovative and dare to take risks.

b. Attention to details. How far the employees can be expected to show accuracy, analysis, and attention to details.

c. Result-Oriented. How far the management focuses on results, not on the techniques and processes used to get the results.

d. People-Oriented. How far the management decisions able to calculate the effects of their results on the people in the organization.

e. Team-Oriented. How far work activities are organized in work teams, not individuals.

f. Aggressiveness. How far people are aggressive and competitive, not relaxing.

g. Firmness. How far the organization's activities emphasize maintaining status as opposed to growth or innovation.

\subsection{Employee Communication}

The success of human resource processes can not be separated from the success of the role of communication between employees in an organization. Communication failure can have an impact on organizational failure. Furtherly, communication can be defined as a process of exchanging information between individuals through an ordinary system, with symbols, signals, even behavior or actions [7]. Other experts say that communication is an act of sharing information, ideas or opinions of each communication participant that involved in achieving similarity of meaning [8]. Furthermore, employee communication can be explained as an effort to exchange information between individuals within an organization through channels that have been set by the company.

In this research, human resource processes that involve employee communication can not be separated from the following indicators:

a. Communication from top to bottom or vice versa.

b. Communication from top to bottom or vice versa is communication between employees to the leadership or vice versa, it can be in the form of oral or written, through agreed communication channels.

a. Horizontal communication.

c. Is communication that occurs between parts of the same level / equal position in an organization. 
a. Diagonal communication

d. It is communication that is woven between two or more of different parts/levels in one organization.

\subsection{Leadership Style}

Leadership plays an important role in managing human resources in the organization. One of the keys to organizational success in achieving goals is leadership. Leadership is the ability to influence groups towards achieving goals [9]. Furthermore, Suwatno and Prensa [9] states that leadership is:

a. Includes the use of influence and that all relationships can involve the leader.

b. Leadership includes the importance of the communication process. The clarity and accuracy of communication affect the behavior and performance of followers.

c. Leadership focuses on the goals to be achieved. Effective leaders must relate to the goals of individuals, groups, and organizations.

In line with the opinion above, Bennis [10] states that leadership is a process to influence employees to act and behave in certain ways as expected by a leader. Regarding leadership, it can be said that each individual has a different character in leading. Leadership style can be defined as the norm of behavior used by someone when the person tries to influence the behavior of others or subordinates [11]. Leadership style is the nature, habits, temperament, character, and personality that distinguishes a leader in interacting with others [12].

From the explanation of the leadership style mentioned above, it can be explained several indicators of leadership style as below [8].

a. Autocratic type, by characterizing organizations as private property, identifies personal goals with organizational goals, consider subordinates as mere tools, do not want to accept criticism, suggestions, and opinions and are too dependent on formal power.

b. Militaristic Type, with characteristics in moving subordinates more often using the command system, in moving subordinates like to depend on the rank and position, be willing at excessive formalities, demanding high discipline and stiffness from subordinates, difficult to accept criticism from subordinates and fond of ceremonies for various circumstances.

c. Paternalistic type, with the characteristics of assuming subordinates as human beings who are not mature, being overly protective, rarely provide opportunities for subordinates to take part in making decisions and rarely give opportunities to subordinates to take the initiative.

d. Charismatic type. Theoretically, the type of charismatic is difficult to analyze where there are characteristics of the strength of the power so that it can attract very large followers.

e. Democratic type, with characteristics, always trying to align the interests and goals of the organization with personal interests and goals, happy to receive advice, opinions and even criticism from his subordinates, trying to develop the capacity of his personal self as a leader.

f. Laissez-Faire type. More leads to the view that generally, the organization will run smoothly by itself because the members of the organization consist of mature peoples who know what the organization's goals are. 


\subsection{Work Motivation}

To carry out an effort to achieve goals, a strong motivation is needed. Motivation comes from Latin's word Movere which means encouragement or driving force. Sedarmayanti states that motivation can be interpreted as a driving force, which causes people to do something or they do something because they are afraid of something [13]. Furthermore, it can be explained that work motivation is things that encourage or motivate a person to do work that is his responsibility in an effort to achieve goals.

In an effort to carry out tasks related to responsibility, then employees should have the motivation, both arising from within themselves (intrinsic) or from outside the individual (extrinsic). Based on the meaning of motivation above, it can be said that work motivation is the response of employees to a number of statements regarding all business activities that arise from within the employee in order to grow the urge to work and the goals desired by the organization can be achieved. Furthermore, the motivation indicators in this research can be explained as follows [9].

a. Intrinsic Motivation is the motive that becomes active or functioning does not need to be stimulated from the outside, because in every individual there is an urge to do something.

b. Extrinsic Motivation is motives that are active and functioning because of stimuli from the outside.

\section{Method}

\subsection{Research Hypothesis}

In Literature Review stated earlier, where the concept of organizational culture, employee communication, leadership style, and work motivation are used, the hypothesis proposed in this research are:

a. There is a significant influence between organizational culture, employee communication, and leadership style togetherly on work motivation.

b. There is a significant influence between organizational culture, employee communication, and leadership style partially on work motivation.

Research Location

This research took place at the Coffee Toffee Café in Surabaya, including in East Java Expo. A. Yani Street, Surabaya.

\subsection{Research Model}

Organizational culture is a process that systematically examines the state of human resources to ensure that the amount and quality with the right skills, will be available when they are needed[9] with indicators of innovation and risk-taking, attention to details, resultsoriented, people-oriented, team-oriented, aggressiveness and firmness [6].

Employee Communication can be explained as an effort to exchange information between individuals in one organization through channels that have been set by the company, with indicators such as communication from top to bottom or vice versa, horizontal communication, diagonal communication.

Leadership style can be interpreted as a norm of behavior used by someone when the person tries to influence the behavior of others or subordinates [11] with indicators such as autocratic, militaristic, paternalistic, charismatic, democratic and Laissez-Faire. 
Work motivation is things that encourage or background a person to do the work that is his responsibility in an effort to achieve goals, with indicators such as intrinsic motivation and extrinsic motivation.

\subsection{Data Collection Method and Research Instrument}

Data collection and research instrument to be used is questionnaire The desired questionnaire is to determine employee work motivation seen from organizational culture, communication between employees and leadership style. The questionnaire was sent to the respondent with the matter above. Regarding research problems, the questionnaire used was a closed-ended questionnaire.

\subsection{Research Design}

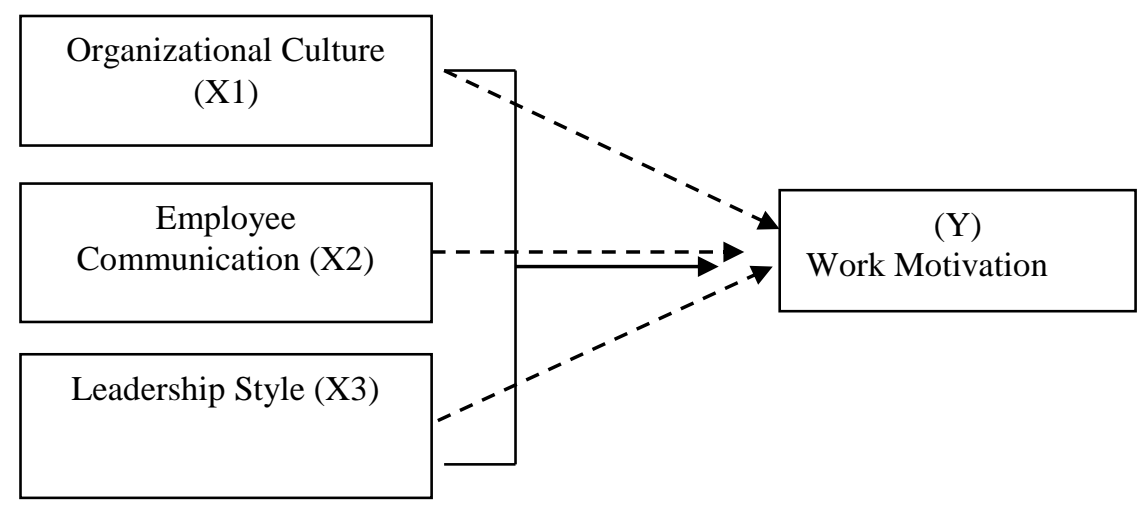

Figure 3. Research Design Diagram

: independent variables simultaneously affect the dependent variable.
: independent variable partially affects the dependent variable.

\subsection{Techniques Of Data Collection And Data Analysis}

Relate to the problems that have been raised, the population in this study are all Coffee Toffee employees, 100 employees, while the sample of this study was taken randomly. This research using Slovin's calculation formula [14]. By using the Slovin's formula, the following equation is obtained.

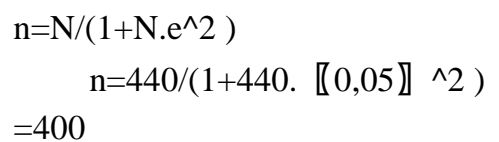

Furthermore, the data analysis in this research is as follows.

a. Descriptive Statistics Analysis

Descriptive statistics analysis is used to explain and describe the data obtained and find the values needed in inferential statistics. This analysis is also used to answering the question "How the organizational culture, employee communication, and leadership style formed at the Coffee Toffee Café in Surabaya?". 
In descriptive statistics analysis the data presentation is done by:

1) Mean (Average)

As a measure of location, it is used to determine the state of loading of answers from each respondent.

2) Percentage

To find out the number of respondents in the category.

b. Inferential Statistics Analysis

The use of inferential statistics analysis in this study is by using Multiple Linear Regression. In general, Multiple Regression equations for populations are as follows:

$\mathrm{Y}=\beta \_0+\beta \_1 \mathrm{X} \_1+\beta \_2 \mathrm{X} \_2+\beta \_3 \mathrm{X} \_3+\cdots+\beta \_\mathrm{n} X \_\mathrm{n}+\varepsilon$ used in this research are:

$\mathrm{Y}=\beta \_0+\beta \_1 \mathrm{X} \_1+\beta \_2 \mathrm{X} \_2+\beta \_3 \mathrm{X} \_3+\varepsilon$

Where:

$$
\begin{array}{ll}
\text { Y } & : \text { Work motivation } \\
X \_1 & : \text { Organizational culture } \\
\text { X_2 } & : \text { Employee Communication } \\
\text { X_3 } & : \text { Leadership Style } \\
\beta \_0 & : \text { Constant } \\
\beta \_1, \beta \_2, \beta \_3 & : \text { Regression Coefficient } \\
\varepsilon_{-} & : \text {Disturbance Variable }
\end{array}
$$

Multiple linear regression models for this population can be estimated based on a random sample sized ? with a linear model for the sample as follows:

(3)

$$
\mathrm{Y}=\mathrm{b} \_0+\mathrm{b} \_1 \quad \mathrm{X} \_1+\mathrm{b} \_2 \quad \mathrm{X} \_2+\mathrm{b} \_3 \quad \text { X_3 }
$$

Where:

$\beta \_1, \beta \_2, \beta \_3$

$\begin{array}{ll}\mathrm{Y}^{\wedge} & \text { : Work motivation } \\ \mathrm{X} \_1 & \text { : Organizational Culture } \\ \mathrm{X} \_2 & \text { : Employee Communication } \\ \mathrm{X} \_3 & \text { : Leadership Style } \\ \mathrm{b} \_0 & : \text { Estimation of constant parameters } \beta \_0 \\ \text { b_1,b_2,b_3 } & \text { :Estimates of the regression coefficient parameters }\end{array}$

\subsection{Results and Outreach Achieved}

Data processing is carried out, begin with several preliminary stages that have been carried out by the researcher as a condition for performing data processing, some of that includes testing the validity and reliability of the instrument, conducted by testing the instrument on 18 students who had worked, both in the formal sector and the informal sector to resemble the actual conditions. The next step if the results of the testing of the instrument are found questionnaire questions with the total correlation value (r) less than 0.250 then the question item will be deleted. When testing this instrument, it was found that there were questions with total correlation values (r) less than 0.250 so that the question item declared invalid and deleted, then after the results are known, the classical regression assumption test then carried out, followed by a regression test. The following is an explanation of the results of the validity test and reliability of the instrument. 
Multiple Linear Regression Test

Multiple linear regression test was conducted to determine the effect of organizational culture variables, employee communication, leadership style and employee motivation with the following research variable regression equation:

$\mathrm{Y}=\mathrm{a} 0+\mathrm{b} 1 \mathrm{X} 1+\mathrm{b} 2 \mathrm{X} 2+\mathrm{b} 3 \mathrm{X} 3+\mathrm{ei}$

Where:

$\mathrm{Y}=$ Work Motivation

$\mathrm{a} 0=$ Constant

$\mathrm{b} 1-\mathrm{b} 3=$ Regression Coefficient

$\mathrm{X} 1=$ Organizational culture

$\mathrm{X} 2$ = Employee Communication

X3 = Leadership Style

ei $=$ Disturbance Variable

The table below was the test results using SPSS 20 for Windows.

Coefficientsa

Model Unstandardized Coefficients Standardized Coefficients

B Std. Error Beta

$1 \quad$ (Constant) $\quad-1.642 \quad 3.799 \quad 668$

$\begin{array}{lllllll}\text { Organizational culture } & .202 & .078 & .424 & 2.578 & .014\end{array}$

$\begin{array}{llllll}\text { Employee Communication-.081 } & .153 & -.085 & -.529 & .600\end{array}$

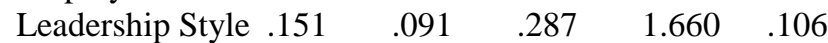

a. Dependent Variable: Work Motivation

The multiple linear regression testing that has been done produces the regression equation as follows:

$\mathrm{Y}=-1,642+0,202 \mathrm{X} 1+(-0,081 \mathrm{X} 2)+0,151 \mathrm{X} 3$

From the test results, it can be explained that organizational culture, employee communication, and leadership style have an influence on work motivation, this is explained further as below :

Constant Value $=-1,642$

This value indicates if the variables $\mathrm{X} 1$ and $\mathrm{X} 2$ are in constant condition, then the work motivation variable $(\mathrm{Y})$ is $-1,642$ units.

Value of $\mathrm{b} 1=0,202$

This value has meaning if the positive regression coefficient with the influence condition unidirectional between organizational culture variables (X1) with work motivation (Y) which means if there is an addition to the organizational culture variable as much as 1 unit then work motivation will increase by 0.202 assuming other variables not changed.

Value of $b 2=-0,081$

This value shows the opposite effect of employee communication variables with work motivation variables, with an explanation if there are additions to employee communication variables as much as 1 unit then work motivation will decrease by 0.081 assuming other variables remain.

Value of $b 3=0,151$

The above values show a direct and positive influence between the leadership style variables and employee wok motivation, with an explanation if there are additions to the leadership style variables of 1 unit then the employee work motivation variable will increase by 0.151 assuming other variables remain. 


\title{
Proof of Hypothesis
}

In this research, proving the hypothesis done by testing $\mathrm{F}$ to determine the effect simultaneously of organizational culture variables, employee communication, leadership style, and work motivation. The test results can be seen in the following table.

\author{
ANOVAa \\ Model Sum of Squares df Mean Square F $\quad$ Sig. \\ $\begin{array}{lllllll}1 & \text { Regression } & 56.489 & 3 & 18.830 & 6.318 & .001 \mathrm{~b}\end{array}$ \\ Residual 107.286 $36 \quad 2.980$ \\ Total 163.77539 \\ a. Dependent Variable: Work Motivation \\ b. Predictors: (Constant), Leadership Style, Employee Communication, Organizational
} Culture

From the table above it is known that the value of Fcalc is 6,318 with a significance level of 0.001 . In these conditions a significance level of 0.001 is less than 0.05 , so the first hypothesis stated "There is a significant influence between the variables of organizational culture, employee communication, leadership style on work motivation." Declared accepted. And the second hypothesis which stated "There is no significant influence between the variables of organizational culture, employee communication, leadership style on work motivation." Declared rejected.

Furthermore, to determine the effect of variable organizational culture, employee communication and leadership style together on work motivation is known from the magnitude of multiple determination coefficients (R2) that is equal to 0.363 which indicates that 36.3 changes in $\mathrm{Y}$ variables are influenced by all three $\mathrm{X}$ variables, in other words the remaining measurements of $63.7 \%$ are influenced by other variables not measured by the analysis model.

\section{Result and Discussion}

In testing that has been done with regression tests, there is a partial influence between organizational culture variables on work motivation with beta values is 0.424 so that it can be conveyed that the organizational culture variable has a considerable influence, but not up to $50 \%$ $(42.4 \%)$ at a significance level of 0.014 which is smaller than 0.05 . With these conditions, it can be explained that organizational culture is a factor that is quite influential in the organization. Culture can be in the form of habits and behavior of members of the organization that have been agreed upon in carrying out their duties. At the Coffee Toffee café, the culture can be seen in the behavior of employees who are always obedient to the rules, by carrying out duties according to company requirements, including enthusiasm in serving and providing education to consumers about the coffee beverage products offered. From the various conditions, organizational culture can be formed according to the characteristics of the Coffee Toffee café which leads to easy, simple and fun, according to the motto that they apply to the service and products presented.

The next test is the employee communication variable on work motivation with a value of beta -0.085 at a significance level of 0.600 and greater than 0.05 so that it can be said that employee communication has no significant effect on employees work motivation. With these conditions, it can be explained that communication carried out by employees is not directly related to work and work motivation is formed with patterns outside of employee communication. 
The next partial test is the leadership style variable on work motivation where the beta value obtained is 0.287 with a significance level of 0.106 which is greater than 0.05 so that it can be said that the leadership style does not significantly influence employee motivation. Explanation of these conditions is likely from the maturity factor of the employee's mindset in working so that it does not depend on leadership style and continues to perform tasks well, with any leadership style the task is still carried out properly to achieve organizational goals.

Simultaneous testing carried out for three independent variables, namely organizational culture, employee communication, and leadership style gave a not too large influence with the amount of $36.3 \%$ on work motivation. It can not be denied that organizational culture, employee communication, and leadership style are key factors related to the existence of employee motivation. It can be explained that in the element of motivation there are various factors that are part of the motivation itself, including organizational culture, communication and leadership style. These three variables form a power within the employee's self and converged to be the motivation to carry out the task well.

\section{Conclusion}

In the partial testing that has been done, it can be concluded that the organizational culture variable influence employee work motivation. This condition can be explained that organizational culture is an important part of employee motivation. At the Coffee Toffee café, organizational culture can be seen in the behavior of employees who are always obedient to the rules and regulations of the company, by carrying out tasks according to the mutually agreed guidelines and norms in the company, including enthusiasm in serving and educating consumers about coffee drink products they offered. From the various conditions, organizational culture can be formed according to the characteristics of the Coffee Toffee café which leads to easy, simple and fun, according to the motto that they apply to the service and products they presented. On employee communication variable and leadership style variable, from the results of the partial test, it is known that these two variables do not significantly influence employee communication and leadership style. This condition can be explained that communication carried out by employees is in another dimension outside the research and not related to work motivation. The same thing also happened to leadership style variable that did not significantly influence work motivation. This can occur because of several possibilities, one of the possibilities is the maturity factor of the employee's mindset in working, so it does not depend on leadership style and continues to carry out the task well.

\section{References}

[1] I. A. I. Giantari and I. G. Riana, "Pengaruh Budaya Organisasi Terhadap Motivasi Kerja Dan Kinerja Karyawan Klumpu Bali Resort Sanur," E-Jurnal Manaj. Univ. Udayana, vol. 6, no. 12, 2017.

[2] F. C. Lunenburg, "Organizational Culture-Performance Relationships Views of Excellence and Theory Z," Natl. Forum Educ. Adm. Superv. J., vol. 9, no. 4, pp. 1-10, 2011.

[3] A. M. Awadh and M. S. Alyahya, "Impact of organizational culture on employee performance," Int. Rev. Manag. Bus. Res., vol. 2, no. 1, p. 168, 2013.

[4] M. J. King, “Deep culture,” J. Pop. Cult., vol. 45, no. 4, pp. 687-694, 2012.

[5] B. O. Wibowo, Sebuah kebutuhan untuk meningkatkan kinerja jangka panjang. Jakarta: PT. Raja Grafindo Persada, 2011. 
[6] S. P. Robbins and T. A. Judge, Perilaku Organisasi. Jakarta: Salemba Empat, 2015.

[7] P. Djoko, Komunikasi Bisnis. Jakarta: Erlangga, 2011.

[8] S. Arifin, Leadership Ilmu dan Seni Kepemimpinan. Jakarta: Mitra Wacana Media, 2012.

[9] H. Suwatno and D. J. Priansa, Manajemen SDM dalam organisasi Publik dan Bisnis. Bandung: Alfabeta, 2011.

[10] B. Warren, Why leaders can't lead: the unconscious conspiracy continues. San Francisco, CA: Jossey-Bass, 1989.

[11] T. Miftah, Kepemimpinan dalam manajemen. Jakarta: Rajawali Pers, 2010.

[12] K. Kartono, Pemimpin dan kepemimpinan: apakah kepemimpinan itu abnormal. Jakarta: Rajawali, 2008.

[13] Sedarmayanti, Perencanaan dan Pengembangan Sumber Daya Manusia. Jakarta: Refika Aditama, 2017.

[14] J. Supranto, Teknik Sampling untuk Survei \& Eksperimen. Jakarta: Rineka Cipta, 2007. 